https://doi.org/10.25143/socr.14.2019.2.009-022

\title{
leguldītāju aizsardzības mehānisma attīstības tendences: normatīvo aktu grozijjumi 2017. un 2018. gadā
}

\author{
Mg. iur. Tatjana Jukna \\ Rīgas Stradina universitāte, Doktorantūras nodaḷa, Latvija \\ Tatjana.Jukna@gmail.com
}

\section{Kopsavilkums}

Ieguldītāju aizsardzības mehānisms ir diezgan jauns tiesību institūts, ${ }^{1}$ kura elementi ietverti vairākos Latvijas Republikas un Eiropas Savienības normatīvajos aktos. Ieguldītāju aizsardzības problemātikas aktualitāti veicina gan globalizācija, gan tehnolog̣iju attīstība, kā arī jaunu finanšu instrumentu veidu rašanās.

Ieguldītāju aizsardzības pasākumu attīstību Latvijas tiesiskajā regulējumā būtiski ietekmē Eiropas Savienības normatīvā regulējuma pārṇemšana nacionālajā tiesību sistēmā.

Šajā rakstā skartas personu kā ieguldītāju tiesības, kas cieši saistītas ar vērtspapīru kā patstāvīgu privāttiesiskas apgrozības priekšmetu, t. i., ieguldītāju aizsardzības pamatelementi aplūkoti ieguldījumu pakalpojumu kontekstā. Taču šeit netiek aplūkotas akcionāru, obligacionāru, ieguldījumu apliecību īpašnieku tiesības, kas izveidojas no īpašumtiesībām uz vērtspapīriem ar tieši vērtspapīrā nostiprinātajām tiesībām (piemēram, ar izpirkuma tiesībām, balsstiesībām, tiesībām uz informāciju u. c.).

Atslēgvārdi: ieguldītāji, ieguldītāju aizsardzība, MiFID, finanšu instrumenti, Finanšu instrumentu tirgus likums, repo darïjumi.

\section{levads}

Rakstā sniegts ieskats jautājumos par ieguldītāju aizsardzību un ieguldītāju aizsardzības mehānisma attīstības tendencēm Latvijas Republikas normatīvajā regulējumā.

\footnotetext{
1 Atsevišk
} 
Tatjana Jukna. Ieguldītāju aizsardzības mehānisma attīstības tendences: normativo aktu grozijumi 2017. un 2018. gadā

Atbilstoši Akadēmisko terminu datubāzē publicētai definīiijai jēdziens "ieguldītājs" ir diezgan plašs. Tajā ietvertas "personas vai organizācijas, kas iegādājas īpašumu, akcijas, vērtspapīrus u. c., lai tos pārdotu un gūtu peḷnu vai saṇemtu naudu procentu maksājumu vai dividenžu veidā" [13]. Ieguldītāju aizsardzības mehānismu veidojošie elementi tiek aplūkoti ieguldījumu pakalpojumu kontekstā.

Raksta mērḳis ir noteikt ieguldītāju aizsardzības mehānisma attīstības tendences Latvijas normatīvajā regulējumā 2017. un 2018. gadā.

Publikācijas sagatavošanā tika izmantota analītiskā, aprakstošā, kā arī interpretācijas (gramatiskā, vēsturiskā, sistēmiskā un teleoloǵiskā) metode, analizēti Latvijas Republikas normatīvie akti un zinātniskā literatūra.

\section{Jēdzieni "ieguldītājs" un "investors" Latvijas Republikas normatīvajā regulējumā}

Vienīgais Latvijas likums, kurā ietverta jēdziena "ieguldītājs" definīcija, ir Ieguldītāju aizsardzības likums [6]. No šā likuma 1. panta trešajā un sestajā punktā sniegtajām definīcijām izriet, ka ieguldītājs ir persona, kas nodod naudu vai finanšu instrumentus ieguldījumu pakalpojuma sniegšanai juridiskai personai, kura noteiktā kārtībā ir saṇēmusi nepieciešamo Finanšu un kapitāla tirgus komisijas licenci.

Analizējot šo definīciju, jāpievērš uzmanība tam, ka ieguldītājs nodod naudu ieguldījumu pakalpojumu sniegšanai. Savukārt jēdziens "ieguldījumu pakalpojums" tiek skaidrots vienīgi Finanšu instrumentu tirgus likuma [3] (turpmāk - FITL) 3. panta ceturtajā dạ̦ā, ārpus definīcijā ietverto personu loka atstājot personas, kas saṇem ieguldījumu blakus pakalpojumus, kuri minēti FITL 3. panta piektajā dạ̦ā, kā arī citas personas, kas nodod savu naudu, piemēram, alternatīvajam ieguldījumu fondam $u$. tml.

Var secināt, ka Ieguldītāju aizsardzības likumā jēdziens "ieguldītājs" izmantots šaurākā nozīmē, nekā tas tiek lietots citā normatīvajā regulējumā un praksē, jo jēdzienu "ieguldītājs" (praksē arī jēdzienu "investors") attiecina gan uz akcionāriem un fondu dalībniekiem, gan uz obligacionāriem šo personu tiesību aizsardzības kontekstā, t. i., viṇu tiesībām uz informāciju par emitentu, tiesībām piedalīties korporatīvajās sapulcēs, mazākumakcionāru tiesību aizsardzību u. c.

Finanšu instrumentu tirgus likums ir viens no likumiem, kura mērḳis tiek sasniegts ar ieguldītāju aizsardzības veicināšanu (2. panta pirmais punkts). FITL nav ietverta ieguldītāja definīcija, bet pats jēdziens "ieguldītājs" likumā lietots vairāk nekā 90 reizes, un bieži šis jēdziens tiek lietots gan kopā ar jēdzienu "klients”, gan, it īpaši likuma F sadal̦ā "Ieguldījumu pakalpojumi", saistībā ar personu, kas iegulda līdzekḷus finanšu instrumentā (vērtspapīrā). Tādējādi var uzskatīt, ka FITL izpratnē pārklājas jēdzieni "klients" un "ieguldītājs" jeb persona, kas saṇem ieguldījumu pakalpojumu vai ieguldījumu blakus pakalpojumus. 
Jēdziens "ieguldītājs" tiek lietots arī citos Latvijas Republikas likumos, ${ }^{2}$ un tajos tiek saistīts ar:

- līdzekḷu ieguldījumu finanšu instrumentā (vērtspapīrā); ${ }^{3}$

- ieguldijumu pakalpojumu;

- komplektēto privāto ieguldījumu produktu pārdošanu (šĩ ir jauna tendence, kas novērojama kopš 2017. gada).

Latviešu valodā vārdam "ieguldītājs" līdzīga satura vārds ir "investors". Praksē tie abi bieži tiek izmantoti (sk., piemēram, [5; 19]). Jēdziens "investors" lietots vairākos Latvijas Republikas likumos, piemēram, Jaunuzñēmumu darbības atbalsta likuma 5. panta pirmajā dạ̦ā [9], kura satur riska kapitāla kvalificēta investora jēdzienu: "[..] persona vai lietu kopība [..], kas reǵistrēta kā alternatīvo ieguldījumu fonds Latvijā atbilstoši Alternatīvo ieguldījumu fondu un to pārvaldnieku likumam [..]", un likumā nosaukti kritēriji atzī̌sanai par riska kapitāla kvalificēto investoru. Riska kapitāla kvalificēta investora jēdziens secīgi tiek izmantots arī Imigrācijas likumā [8].

Abu jēdzienu (ieguldītājs un investors) lietošana normatīvos aktos ir likumsakarīga, jo jēdziens "kvalificētais ieguldītājs" tiek plaši izmantots gan FITL, kurā noteikti kritēriji atzīšanai par kvalificētu ieguldītāju, gan Ieguldījumu pārvaldes sabiedrību likumā, gan Alternatìvo ieguldījumu fondu un to pārvaldnieku likumā. Pēdējie divi tiesību akti secīgi atsaucas uz FITL.

Divu atšḳirīgu procesu apzīmējumam normatīvajos aktos tiek izmantoti dažādi jēdzieni, lai praktiskajā piemērošanā tie netiktu sajaukti, kaut arī pēc būtības "ieguldītājs" un "investors" ir sinonīmi. Atbilstoši Eiropas terminu bankai (EuroTermBank) vārds investor no angḷu valodas latviešu valodā tiek tulkots gan kā ieguldìtājs, gan kā investors, gan kā kapitālieguldītājs [16], turklāt jēdziens "ieguldītājs" Eiropas Komisijas Ekonomikas un pārvaldes terminu vārdnīcā (Dictionary of Economic and Management Terms) skaidrots kā "persona vai organizācija, kas iegādājas īpašumu, akcijas, vērtspapīrus u. c., lai tos pārdotu un gūtu peḷnu vai saṇemtu naudu procentu maksājumu vai dividenžu veidā" [16], jēdziens "investors" netiek skaidrots, bet izvērsts paskaidrojums dots jēdzienam "kapitālieguldītājs" ("fiziska vai juridiska persona, kas iegulda savu kapitālu uzṇēmumā, pasākumā u. c., līdz ar to iegūstot îpašnieka tiesības" [16]).

2 Alternatīvo ieguldījumu fondu un to pārvaldnieku likumā [1] jēdziens “ieguldītājs” minēts180 reizes (saistībā ar personu, kas iegulda līdzekḷus alternatīvajā ieguldījumu fondā vai ir alternatīvā ieguldījuma fonda dạı îpašnieks); Ieguldījumu pārvaldes sabiedrību likumā [7] - 273 reizes (saistībā ar personu, kas iegulda līdzekḷus ieguldījumu fondā vai ir ieguldỉjuma fonda apliecību īpašnieks), Kredītiestāžu likumā [10] - trīs reizes (saistībā ar komplektēto privāto ieguldījumu produktu pārdošanu - 72. ${ }^{2}$ pants un 113. panta piektās daḷas ceturtais punkts, stājās spēkā 21.07.2017., 108. ${ }^{1}$ panta sestajā daḷā - saistībā ar kredītiestādes pakalpojumu saṇēmēju, tostarp ieguldītāju interešu aizsardzību krīzes apstākḷ̆os - kopš 2007. gada), Finanšu un kapitāla tirgus komisijas likumā [5] - četras reizes.

3 Jēdziens "ieguldītājs" tika ietverts arī likumā "Par vērtspapīriem" [12] ("ieguldìtājs - šã likuma izpratnē: persona, kas savā vārdā un uz sava rēḳina iegūst vērtspapīros nostiprinātās tiesības"), kas zaudēja spēku ar FITL spēkā stāšanos. 
Tatjana Jukna. Ieguldītāju aizsardzības mehānisma attīstības tendences: normativo aktu grozijumi 2017. un 2018. gadā

Tādējādi var secināt, ka ieguldītāja mērḳis ir "darbības nolūkā saṇemt peḷnu", tostarp no vērstpapīru tirdzniecības, savukārt kapitālieguldītāja mērḳis ir īpašumtiesību iegūšana, respektīvi, tāds ieguldīšanas veids, kas saistīts ar kapitāla izvietošanu, pārṇemot noteiktu kontroli pār uzñēmumu vai veidojumu u. tml.

Tātad ieguldītājs ir persona, kas nodod naudu. N̦emot vērā mūsdienu finanšu instrumentu tirgus infrastruktūras specifiku, ieguldītājs var veikt tirdzniecību ar finanšu instrumentiem, t. i., noslēgt pirkšanas-pārdošanas darījumus, izmantojot tikai ieguldījumu pakalpojumu sniedzēju pakalpojumus, savukārt investors var pārṇemt kontroli pār uzṇēmumu bez ieguldījumu pakalpojumu sniedzēju starpniecības.

\section{leguldītāju aizsardzība}

Latvijas Republikas normatīvajos aktos, tāpat kā Eiropas terminu bankā, nav jēdziena "ieguldītāju aizsardzība", savukārt "aizsardzība" tajos izmantots visdažādākajās variācijās: dabas aizsardzība, datu aizsardzība, diplomātiskā aizsardzība, patērētāju aizsardzība. Pats termins "aizsardzība" tiek izmantots diezgan plašā kontekstā, tas ietver arī "valsts pasākumu sistēmu iedzīvotāju un sabiedrības aizsardzībai pret nevēlamām parādībām" [18, 10]. Var secināt, ka "ieguldītāju aizsardzība" ir valsts pasākumu sistēma ieguldītāju aizsardzībai pret nevēlamām parādībām. Bet arī šis skaidrojums neatklāj jēdziena "ieguldītāju aizsardzība" būtību. Joprojām neatbildēts paliek jautājums: "Pret kādām nevēlamām parādībām ieguldītājs jāaizsargā?"

Viennozīmīgu atbildi uz šo jautājumu sniegt nav iespējams, jo, attīstoties sabiedrībai, vienmēr uzrodas jaunas parādības un notikumi, kas ne vienmēr ir vēlami ieguldìtājam.

Kembridžas vārdnīcā (Cambridge Dictionary), piemēram, "ieguldītāja aizsardzība" skaidrota kā aizsardzība, kas ir vērsta uz to:

- lai ieguldītāji nezaudētu naudu gadijumos, kad ieguldījums netiek atmaksāts;

- lai ieguldītāji nezaudētu naudu gadījumos, ja cilvēki saṇem no vin̦iem naudu negodīgi;

- lai ieguldītājam netiktu pārdoti finanšu produkti, kuri ieguldītājam nav vajadzīgi vai tie, kas izraisīs naudas līdzekḷu zaudēšanu. [15]

Savukārt Financial Times leksikonā ieguldītāju aizsardzība definēta kā darbības nolūkā nodrošināt godīgu finanšu produkta reklamēšanu un novērst krāpšanu, lai nodrošinātu, ka ieguldītājs nezaudēs naudu gadījumā, ja ieguldījums izrādīsies neveiksmīgs (netiks atmaksāts) [17].

Abas definīcijas savstarpēji korelē: ieguldītāju būtu jāpasargā no naudas zaudēšanas. Attīstot šo domu, rodas jautājums, vai ieguldītājs nedrīkstētu zaudēt naudu vispār vai tomēr noteiktos gadījumos būtu jāparedz tādi pasākumi un mehānismi, kas, pirmkārt, izveidotu ieguldītājam maksimāli labvēlīgu infrastruktūru un, otrkārt, paredzētu zaudējumu kompensācijas mehānismus?

Atbilde ir acīmredzama un nepārprotama: ja tiek veidota aizsardzības nevis apdrošināšanas sistēma, tad tiek radīta ieguldītājam maksimāli labvēlīga infrastruktūra, kurā 
Tatjana Jukna. Ieguldītāju aizsardzības mehānisma attīstības tendences: normativo aktu grozijumi 2017. un 2018. gadā

var ietvert arī apdrošināšanas sistēmas elementus, piemēram, kompensācijas sistēmas, ${ }^{4}$ bet kopumā tiek veidota ieguldītājam labvēlīga un taisnīga tiesiskā vide, kurā ieguldītājs var pienemt ieguldījumu lēmumu, t. i., stāties tiesiskajās attiecībās, noslēdzot finanšu darïjumu un uzṇemoties ar ieguldījumiem saistītus dabiskus riskus. Ieguldītājam labvēlīgas tiesiskās vides izveidošana ir vairāku normatīvo aktu efektīvas mijiedarbības process: gan Latvijas Finanšu instrumentu tirgus likuma, t. i., likuma, kurā noteikti ieguldījumu pakalpojumu sniegšanas nosacījumi un kurā pārṇemtas vairākas ES direktīvas, piemēram, Direktīva par finanšu instrumentu tirgiem (Markets in Finanical Instruments Directive) 2014/65/ES [2], gan Krimināllikuma [11], gan Finanšu un kapitāla tirgus komisijas likuma, gan Finanšu nodrošinājuma likuma [4] un vairāku Eiropas Savienības regulu.

Akcentējot uzmanību uz ieguldītāju aizsardzības jauninājumiem 2017. un 2018. gadā tieši civiltiesiskajā kontekstā, lietderīgi aplūkot Finanšu instrumentu tirgus likuma grozījumus, kas skar ieguldītāju aizsardzības jautājumus ieguldījumu pakalpojumos.

\title{
FITL būtiskākie grozijumi ieguldītāju aizsardzības kontekstā
}

\begin{abstract}
Ieguldītāju aizsardzības sistēmas centrālais likums ir FITL, kas
"regulē finanšu instrumentu publiskā piedāvājuma izteikšanas, finanšu instrumentu publiskās apgrozības, ieguldījumu pakalpojumu un ieguldījumu blakuspakalpojumu sniegšanas un finanšu instrumentu tirgus dalïbnieku licencēšanas un uzraudzības kārtību, nosaka finanšu instrumentu tirgus dalībnieku [..] tiesības un pienākumus, kā arī atbildību par šajā likumā paredzēto prasību neievērošanu" [3, 3. panta pirmā daḷa].
\end{abstract}

FITL stājās spēkā 2004. gadā un nomainīja 1995. gada likumu "Par vērtspapīriem" [12]. FITL 14 gados tika grozīts 28 reizes, galvenokārt grozījumi bija saistīti ar ES tiesību aktu pārṇemšanu nacionālajā tiesību sistēmā. Ieguldītāju aizsardzības jautājumus būtiski skāra 2007. gada 4. oktobrī veiktie grozījumi, ar kuriem nacionālajā sistēmā tika pārn̦emta Eiropas Parlamenta un Padomes 2004. gada 21. aprịla direktīva 2004/39/EK, kas attiecas uz finanšu instrumentu tirgiem un ar ko groza Padomes direktīvas 85/611/EEK un 93/6/ EEK un Eiropas Parlamenta un Padomes direktīvu 2000/12/EK un atcel Padomes direktīvu 93/22/EEK (turpmāk - MiFID) un kuras mērḳis nodrošināt iegulditajiem "augstu aizsardzības līmeni" (turpmāk šie grozījumi - MiFID grozījumi).

Tieši MiFID pārṇemšana Latvijas nacionālajā tiesību sistēmā lika pamatu tai ieguldìtāju aizsardzības sistēmai, ko izmanto arī šobrīd. Taču uzreiz jāatzīmē, ka Latvijas tiesỉbu sistēmā MiFID II vajadzēja pārṇemt līdz 2018. gada 1. janvārim, bet grozijumus FITL bija jāiestrādā līdz 2017. gada 3. jūlijam. Tomēr FITL grozijumu likumprojekts Saeimai tika iesniegts novēloti, un grozījumi stājās spēkā tikai 2018. gada 18. jūlijā (turpmāk - FITL 26. grozijumi). Tie kārtējo reizi ievērojami paaugstināja ieguldītāju aizsardzības pakāpi. Šajā rakstā apskatîti tieši šìs jaunās ieguldītāju aizsardzības sistēmas elementi.

4 Šāda sistēma pastāv arī Latvijā, tā izveidota uz Ieguldītāju aizsardzības likuma pamata. 
Tatjana Jukna. Ieguldītāju aizsardzības mehānisma attīstības tendences: normativo aktu grozijumi 2017. un 2018. gadā

Vienlaikus nepieciešams pieminēt arī citus FITL grozijjumus, kas tika pieṇemti 2017. gadā. Šiem grozỉjumiem nav izškịirošas nozīmes saistībā ar aplūkojamo tematu, tomēr arī tie skar ieguldītāju aizsardzības jautājumus plašāā kontekstā.

2017. gada 14. septembrī grozïjumi tika veikti ar mērḳi saskan,ot FITL normas ar jauno Eiropas Savienības regulējumu, kas ieviesa vienotus darbības noteikumus centrālajiem vērtspapīru depozitārijiem. Ar šiem grozijumiem citu organizatorisku noteikumu starpā FITL tika ietvertas minimālas segregācijas prasības, kā arī mēgināts novērst nepilnības kolīziju normu regulējumā (lex rei sitae) un nepilnības saistībā ar dematerializētajiem finanšu instrumentiem, kas tiek turēti, izmantojot ieguldïjumu pakalpojumu starpnieku pakalpojumus, jo iepriekšējais regulējums bija fragmentārs un neskaidrs.

Savukārt grozījumi 2017. gada 21. septembrī tika veikti ar mērkị izpildīt Ekonomiskās sadarbības un attīstības organizācijas (Organisation for Economic Co-operation and Development, OECD) ieteikumu pārskatìt normatīvo regulējumu par saistìto pušu darījumu izvērtēšanu, saskaņošanu un atklāšanu.

FITL grozījumu 2017. gada 10. oktobrī mērḳis bija Latvijas nacionālajā tiesību sistēmā pareizi pārṇemt IV nelikumīgi iegūtu līdzekḷ lu legalizācijas novēršanas direktīvu jeb AML IV (Anti-Money Laundering) direktīvu un FITL saskan,ot ar Noziedzīgi iegūto līdzekḷu legalizācijas un terorisma un proliferācijas finansēšanas novēršanas likumu.

Rezumējot šeit minēto, var secināt, ka 2017. un 2018. gadā tiesību aktu grozījumi (tostarp arī 26. grozījumi) tika veikti ar mērḳi Latvijas tiesību sistēmā pārṇemt Eiropas Savienības normatīvos aktus vai izpildìt starptautisko organizāciju rekomendācijas. Tie būtiski mainīja finanšu tirgus un finanšu pakalpojumu sniegšanas infrastruktūru.

\section{Atsevišḳu ieguldītāju aizsardzības pamatprincipu FITL raksturojums}

Klientu kategorizācija. Ieguldītāju aizsardzībā, līdzīgi kā patēēētāju tiesībās, darbojas vājākās puses aizsardzības nepieciešamības koncepts. Šim mērḳim visi ieguldītāji tiek iedalīit kategorijās: privātie klienti, profesionālie klienti un tiesīgie darījuma partneri. Katru kategoriju mēdz apzīmēt ar jēdzienu "statuss". Privātajam klientam ir vislielākā ieguldītāju aizsardzības pakāpe, savukārt tiesīgajam darījumu partnerim - viszemākā ieguldītāju aizsardzības pakāpe. Vienīgi attiecībā uz privāto klientu darbojas ieguldījumu apdrošināšanas sistēma, kas izveidota saskaṇā ar Ieguldītāju aizsardzības likumu. Atš̌kirībā no patērētāju tiesībām, kurās par patērētāju tiek uzskatītas vienīgi fiziskās personas, par privāto klientu var atzīt gan fiziskās, gan juridiskās personas, t. i., tos klientus, kam nav piešķirts ne tiesīga darījuma partnera, ne profesionāla klienta statuss. Šāda klientu kategorizācijas sistēma tika ieviesta ar MiFID grozijumiem un darbojas 10 gadus.

FITL 26. grozijumi nedaudz mainīja klientu kategorizāciju, nosakot, ka pašvaldības netiek uzskatītas par profesionālo klientu per se. Tāpat kā iepriekš klientiem saglabājās tiesības lūgt ieguldījumu pakalpojumu sniedzēju mainìt pieškirto statusu (palielināt vai samazināt ieguldītāju aizsardzības pakāpi) un piešḳirt profesionālā vai privātā klienta 
Tatjana Jukna. Ieguldītāju aizsardzības mehānisma attīstības tendences: normativo aktu grozijumi 2017. un 2018. gadā

statusu attiecībā uz visiem pakalpojumiem un produktiem vai kādu atsevišḳi: tiesīgais darījumu partneris ir tiesīgs lūgt profesionālā vai privātā klienta statusa piešḳiršanu, profesionālais klients per se ir tiesīgs lūgt tiesīga darījuma partnera vai privātā klienta statusa piešķiršanu, privātais klients ir tiesīgs lūgt profesionālā klienta statusa piešķiršanu.

Ieguldītāju aizsardzības pakāpes palielināšana var notikt vienīgi uz līguma pamata, un ieguldījumu pakalpojumu sniedzējam tiek uzlikts pienākums brīdināt ieguldītāju par ieguldītāju interešu aizsardzības tiesībām, ko tas var zaudēt statusā, kurā paredzēta zemāka aizsardzības pakāpe, savukārt klientam rakstiski jāapliecina, ka vinnš ir sañēmis brīdinājumu un izpratis informāciju par ieguldītāju aizsardzības tiesỉbu zaudēšanu. Šādas situācijas biežāk ir izplatītas klientiem, kas kategorizēti kā privātie klienti un vēlas iegūt profesionāla klienta statusu. Šādos gadỉjumos ieguldỉjumu pakalpojumu sniedzējam rūpīgi jāizvērtē klients, viṇa pieredze un atbilstība noteiktajiem kritērijiem pirms pieškirt profesionāla klienta statusu un noslēgt līgumu par statusa maiṇu. Ieguldỉjumu pakalpojumu sniedzējam ir paredzētas atkāpšanās tiesības no līguma, t. i., tiesības atsaukt pieškirto profesionāla klienta statusu, ja ieguldỉjumu pakalpojumu sniedzēja skatījumā klients vairs neatbilst profesionāla klienta statusam, proti, ieguldījumu pakalpojumu sniedzējam ir tiesības, no vienas puses, vienpusēji palielināt ieguldītāja aizsardzības pakāpi, no otras puses, ar šādu ieguldỉjumu pakalpojumu sniedzēju rīcību klientam var tikt liegta pieeja atsevišķiem ieguldỉjumu pakalpojumiem un produktiem.

Klientu kategorizācija pēc būtības ir pamats ieguldītāju aizsardzības ietvaram (sk. 1. tab.) un pienākumiem, ko likumdevējs uzlicis ieguldījumu pakalpojumu sniedzējam pakalpojumu sniegšanas ietvaros, piemēram, sakarā ar informācijas sniegšanu, ieguldìtāju brīdināšanu par riskiem jeb "ikdienā iespējamiem (varbūtējiem) nelabvēlīgiem notikumiem" [20, 17], kurus ieguldìtājs, iespējams, neapzinās savu personisko îpašību vai pieredzes neesamības dēl.

Svarīgi atzīmēt, ka FITL 26. grozìjumi attiecināmi uz visām ieguldītāju kategorijām un pienākumu sniegt patiesu un nemaldinošu informāciju, tomēr sniedzamās un pārbaudāmās informācijas apjoms atškiras gan atkarībā no kategorijas (statusa), gan no pakalpojumu veida, kas tiek nodrošināts attiecīgajam ieguldītājam.

1. tabula. Saīsināts ieguldītāju aizsardzības pasākumu ietvars sadalījumā pa ieguldītāju kategorijām (pēc statusa); ar X atzīmēti attiecināmie pasākumi, ar N/A - neattiecināmie pasākumi

\begin{tabular}{|c|l|c|c|c|}
\hline \multirow{2}{*}{ Nr. } & \multicolumn{1}{|c|}{ Pasākumi } & $\begin{array}{c}\text { Privātie } \\
\text { klienti }\end{array}$ & $\begin{array}{c}\text { Profesionālie } \\
\text { klienti }\end{array}$ & $\begin{array}{c}\text { Tiesīgie } \\
\text { darijumu } \\
\text { partneri }\end{array}$ \\
\hline \multirow{2}{*}{1.} & Vispārīgie principi un pienākumi & $\mathrm{X}$ & $\mathrm{X}$ & $\mathrm{X}$ \\
\cline { 2 - 5 } & Pienākums sniegt patiesu un nemaldinošu informāciju & $\mathrm{X}$ & $\mathrm{X}$ & Nosacīti \\
\cline { 2 - 5 } & $\begin{array}{l}\text { Pienākums rīkoties kā krietnam, rūpīgam saimniekam } \\
\text { ieguldītāja interesēs }\end{array}$ & $\mathrm{X}$ & $\mathrm{X}$ & $\mathrm{X}$ \\
\cline { 2 - 5 } & Pienākums uzturēt noteiktu organizatorisko kārtību & \multicolumn{2}{|c|}{$\mathrm{X}$} \\
\hline
\end{tabular}


Tatjana Jukna. Ieguldītāju aizsardzības mehānisma attīstības tendences: normatīvo aktu grozijumi 2017. un 2018. gadā

1. tabulas turpinājums no 15. lappuses

\begin{tabular}{|c|c|c|c|c|}
\hline Nr. & Pasākumi & $\begin{array}{l}\text { Privātie } \\
\text { klienti }\end{array}$ & $\begin{array}{l}\text { Profesionālie } \\
\text { klienti }\end{array}$ & $\begin{array}{c}\text { Tiesīgie } \\
\text { darijumu } \\
\text { partneri }\end{array}$ \\
\hline \multirow[t]{10}{*}{2.} & \multicolumn{4}{|c|}{ Informācija, ko ieguldījumu pakalpojumu sniedzējs sniedz ieguldītājam } \\
\hline & Informācija par ieguldījumu pakalpojumu sniedzēju & $X$ & $\mathrm{X}$ & $\mathrm{X}$ \\
\hline & $\begin{array}{l}\text { Informācija par finanšu instrumentu dabu, raksturojumu } \\
\text { un ar tiem asociētajiem riskiem }\end{array}$ & $\mathrm{X}$ & $\mathrm{X}$ & Nosacīti \\
\hline & Informācija, kas paredzēta visiem ieguldītājiem & $\mathrm{X}$ & $\mathrm{X}$ & $\mathrm{X}$ \\
\hline & Informācija, kas paredzēta tikai privātajiem klientiem & $\mathrm{X}$ & $\mathrm{N} / \mathrm{A}$ & $\mathrm{N} / \mathrm{A}$ \\
\hline & Informācija par finanšu instrumentu turēšanu & $X$ & $\mathrm{X}$ & $\mathrm{X}$ \\
\hline & Informācija, kas ir paredzēta visiem klientiem & $\mathrm{X}$ & $\mathrm{X}$ & $\mathrm{X}$ \\
\hline & Informācija, kas ir paredzēta tikai privātajiem klientiem & $\mathrm{X}$ & $\mathrm{N} / \mathrm{A}$ & $\mathrm{N} / \mathrm{A}$ \\
\hline & Informācija par piesaistītajiem aǵentiem & $\mathrm{X}$ & $\mathrm{X}$ & $\mathrm{X}$ \\
\hline & Paziņojumi privātajiem klientiem & $\mathrm{X}$ & $\mathrm{N} / \mathrm{A}$ & $\mathrm{N} / \mathrm{A}$ \\
\hline \multirow[t]{4}{*}{3.} & \multicolumn{4}{|l|}{ Informācija par atlīdzībām un izmaksām } \\
\hline & Vispārēja informācija par komisijām un izmaksām & $\mathrm{X}$ & $\mathrm{X}$ & $\mathrm{X}$ \\
\hline & $\begin{array}{l}\text { Informācija par ex-ante izmaksām (pirms darījuma } \\
\text { noslēgšanas) }\end{array}$ & $\mathrm{X}$ & $\mathrm{N} / \mathrm{A}$ & $\mathrm{N} / \mathrm{A}$ \\
\hline & Informācija par ex-post izmaksām (pirms darījuma izpildes) & $\mathrm{X}$ & $\mathrm{N} / \mathrm{A}$ & $\mathrm{N} / \mathrm{A}$ \\
\hline \multirow[t]{6}{*}{4.} & \multicolumn{4}{|c|}{ Finanšu instrumenta vai pakalpojuma piemērotības vai atbilstības novērtēšana } \\
\hline & Atbilstības pārbaude (zināšanas un pieredzes izvērtēšana) & $X^{*}$ & $* *$ & $\mathrm{~N} / \mathrm{A}$ \\
\hline & $\begin{array}{l}\text { Pien,ēmums par zināšanām un izpratne par Fl, produktu, } \\
\text { pakalpojumu esamību }\end{array}$ & $\mathrm{N} / \mathrm{A}$ & $\mathrm{X}$ & $\mathrm{X}$ \\
\hline & $\begin{array}{l}\text { Piemērotības pārbaude (portfeḷa pārvaldības pakalpojums, } \\
\text { ieguldījumu konsultācija) }\end{array}$ & $X$ & $\mathrm{X}$ & Nosacīti \\
\hline & leguldijjumu mērķis, ieskaitot toleranci pret riskiem & $\mathrm{X}$ & $\mathrm{X}$ & Nosacīti \\
\hline & $\begin{array}{l}\text { Finanšu situācija, spēja uzñemties riskus un ciest } \\
\text { zaudējumus }\end{array}$ & $\mathrm{X}$ & $\mathrm{X}$ & Nosacīti \\
\hline \multirow[t]{4}{*}{5.} & \multicolumn{4}{|l|}{ Rīkojumu nodošana, izpilde, dokumentēšana } \\
\hline & $\begin{array}{l}\text { leguldījumu pakalpojumu sniedzēja pienākumi attiecībā } \\
\text { uz rīkojumu nodošanu un izpildi }\end{array}$ & $\mathrm{X}$ & $\mathrm{X}$ & $\mathrm{X}$ \\
\hline & Pienācīga ieguldītāju rīkojumu apstrāde un saglabāšana & $\mathrm{X}$ & $\mathrm{X}$ & $\mathrm{X}$ \\
\hline & $\begin{array}{l}\text { Paziņojumi par noslēgtajiem darījumiem, izpildītajiem } \\
\text { rīkojumiem }\end{array}$ & $\mathrm{X}$ & $\mathrm{X}$ & $\mathrm{X}$ \\
\hline \multirow[t]{3}{*}{6.} & \multicolumn{4}{|l|}{ Labākais izpildes rezultāts } \\
\hline & Labāka izpildes rezultāta nodrošināšana & $\mathrm{X}$ & $\mathrm{X}$ & Nosacīti \\
\hline & Pienākums nodrošināt rīkojumu izpildes politiku & $\mathrm{X}$ & $\mathrm{X}$ & Nosacīti \\
\hline
\end{tabular}

1. tabulas turpinājumu sk. 17. lappusē

* Parasti netiek izvērtēts vienkāršiem finanšu instrumentiem (FI) un produktiem (execution only).

** Parasti tiek izvērtēts tikai profesionālajiem klientiem (pēc izvēles) un tikai piešḳirot profesionāla klienta (pēc izvēles) statusu. 
Tatjana Jukna. Ieguldītāju aizsardzības mehānisma attīstības tendences: normativo aktu grozijumi 2017. un 2018. gadā

1. tabulas turpinājums no 16. lappuses

\begin{tabular}{|c|c|c|c|c|}
\hline Nr. & Pasākumi & $\begin{array}{l}\text { Privātie } \\
\text { klienti }\end{array}$ & $\begin{array}{l}\text { Profesionālie } \\
\text { klienti }\end{array}$ & $\begin{array}{c}\text { Tiesīgie } \\
\text { darijumu } \\
\text { partneri }\end{array}$ \\
\hline \multirow[t]{4}{*}{7.} & \multicolumn{4}{|c|}{ Darījumu attiecības starp ieguldījumu pakalpojumu sniedzēju un klientiem } \\
\hline & $\begin{array}{l}\text { leguldījumu pakalpojumu sniedzēja un klientu saistību un } \\
\text { pienākumu fiksācija }\end{array}$ & $\mathrm{X}$ & $\mathrm{X}$ & $\mathrm{X}$ \\
\hline & $\begin{array}{l}\text { Rakstveida līguma noslēgšana (rīkojumu izpilde / darijumu } \\
\text { noslēgšana) }\end{array}$ & $\mathrm{X}$ & $\mathrm{X}$ & N/A \\
\hline & Prasības līguma saturam & $\mathrm{X}$ & $\mathrm{X}$ & N/A \\
\hline \multirow[t]{2}{*}{8.} & \multicolumn{4}{|l|}{ Interešu konflikts } \\
\hline & $\begin{array}{l}\text { Informācija par pamudinājumiem (inducements), ko saṇem } \\
\text { ieguldījumu pakalpojumu sniedzējs }\end{array}$ & $\mathrm{X}$ & $\mathrm{X}$ & $\mathrm{x}$ \\
\hline \multirow[t]{2}{*}{9.} & \multicolumn{4}{|l|}{ Dalība ieguldītāju aizsardzības kompensācijas shēmā } \\
\hline & $\begin{array}{l}\text { Tiesības saṇemt kompensāciju ieguldītāju aizsardzības } \\
\text { kompensācijas shēmas ietvaros }\end{array}$ & $\mathrm{X}$ & N/A & N/A \\
\hline
\end{tabular}

Aktīvu šḷirta turēšana jeb segregācija. Ieguldītāju aktīvu un saistīto kontu struktūras segregācijas jautājums tiek risināts gan starptautiskā līmenī, ${ }^{5}$ gan ES līmenī, ${ }^{6}$ gan nacionālo valstu līmenī. Tiesiskais regulējums šajā jautājumā ir plašs, tomēr Eiropas Savienības tiesību aktiem trūkst visaptverošas un sistēmiskas pieejas jautājumam, kas skar gan saistības starp finanšu instrumentu tirgus dalïbniekiem, gan pašus finanšu instrumentus un ar tiem saistīto struktūru tiesisko regulējumu, kā arì izpratni par prasībām saistībā ar nodrošinājuma jautājumiem.

Segregācija ir vienīgais mehānisms, ar kura palīdzību uzraudzības iestādes, likumdevēji un citas varas iestādes cenšas nodrošināt ieguldītāju aktīvu aizsardzību gadījumos, kad maksātnespējas tiesības nav harmonizētas. Tā galvenokārt ir orientēta uz finanšu iestādēm, kas veic klientu aktīvu turēšanu (ieguldījumu pakalpojumu sniedzējiem).

Jēdziena "segregācija" saturs atšḳiras pēc pieejas vai izpratnes, ko tajā iekḷauj attiecīgās valsts tiesību akti.

Pirmkārt, ar jēdzienu "segregācija" apzīmē grāmatvedības procesu, kurā atsevišķi tiek kārtota ieguldītājiem piederošu un pašai iestādei piederošu aktīvu uzskaite. Eiropas Savienības tiesību akti ir vērsti uz aktīvu nodalīšanu, t. i., attiecīgas klientu aktīvu

5 Starptautiskās Vērtspapīru komisijas organizācijas (International Organization of Securities Commissions, IOSCO) kolektīvo ieguldījumu shēmu aktīvu aizsardzības principi, piemēram.

${ }^{6}$ Piemēram, Alternatīvo ieguldījumu fondu pārvaldītāju direktīva (Alternative Investment Fund Managers Directive, AIFMD), Eiropas tirgus infrastruktūras regulējums (European market infrastructure regulation, EMIR), Centrālo vērtspapīru noguldījumu regula (Central Securities Depositories Regulation, CSDR), Pārvedamu vērtspapīru kolektīvo ieguldījumu uzṇēmumu tiesību akta V versija (PVKIU V), Finanšu instrumentu tirgus direktivva (Markets in Financial Instruments Directive, MiFID) / Finanšu instrumentu tirgus regula (Markets in Financial Instruments Regulation, MiFIR). 
Tatjana Jukna. Ieguldītāju aizsardzības mehānisma attīstības tendences: normativo aktu grozijumi 2017. un 2018. gadā

uzskaites kārtošanu ārpus ieguldījumu pakalpojumu sniedzēja bilances tā, lai katrā brīdī varētu noteikt katram klientiem piederošo aktīvu veidu un daudzumu (skaitu).

Otrkārt, ar jēdzienu "segregācija" apzīmē aktīvu fizisku nodalī̌anas procesu, piemēram, aktīvu šḳirto turēšanu, t. i., aktīvu turēšanu atsevišķos augstāka līmeņa kontos, lai nepiel̦autu aktīvu sajaukšanos un ieguldītājiem piederošo aktīvu iekḷaušanu ieguldījumu pakalpojumu sniedzēja īpašumu masā maksātnespējas iestāšanas gadījumā, kā arī lai samazinātu iespēju izmantot klientiem piederošus aktīvus ieguldỉjumu pakalpojumu sniedzēja saistību pret trešajām personām apmierināšanai (nodrošināšanai). Attiecīgās segregācijas prasības Finanšu instrumentu tirgus likumā tika ieviestas ar MiFID grozījumiem, turklāt FITL 26. grozījumi pastiprināja ieguldījuma pakalpojuma sniedzēja pienākumus attiecībā uz ieguldītāja aktīvu segregāciju un drošu turēšanu.

Ieguldijjumu pakalpojumu sniedzējiem ir jāuzṇemas atbildība par finanšu instrumentu iztrūkumu kontos savas neuzmanības dẹḷ. N̦emot vērā, ka ieguldījumu pakalpojumu sniedzējam jārīkojas klienta interesēs kā krietnam un rūpīgam saimniekam, atbildība par finanšu instrumentu iztrūkumu iestājas gadījumos, kad pakalpojumu sniedzējs ir pię̦āvis arī vieglu neuzmanību.

Lai mazinātu finanšu instrumentu turēšanas risku jeb iespēju zaudēt finanšu instrumentus, ieguldījumu pakalpojumu sniedzējam ir pienākums izvērtēt turēšanas ìpatnības un praksi, kas varētu negatīvi ietekmēt ieguldītājus, respektīvi, ieguldījumu pakalpojumu sniedzējam jāizvērtē aktīvu turēšanas režìms katrā jurisdikcijā, īpaši pievēršot uzmanību aktīvu aizsardzībai kontrahenta maksātnespējas gadījumos. Ieguldītāju aizsardzības nolūkā katru gadu jāveic šḳirtas turēšanas audits, un uzraudzības iestādei jāiesniedz audita rezultāti. Šādā veidā tiek nodrošināta lielāka ticamība tam, ka ieguldījumu pakalpojumu sniedzējs ievēro Finanšu instrumentu tirgus likumā uzliktos pienākumus. Šāda pieeja Latvijas normatīvajā regulējumā tika ietverta ar MiFID grozijumiem. FITL 26. grozījumi tikai pastiprināja šķirtās turēšanas prasības, ieviešot papildu pienākumus ieguldījumu pakalpojumu sniedzējam, piemēram, nepiel̦aut, lai aktīvi būtu apgrūtināti ar trešo personu (kontrahentu) tiesībām, un gadījumos, ja aktīvi ir vai būs apgrūtināti, par to informēt ieguldītāju. Respektīvi, ieguldījumu pakalpojumu sniedzēja atbildībai par finanšu instrumentu iztrūkumu kontrahenta maksātnespējas gadījumā nevajadzētu iestāties tikai gadījumā, ja pakalpojumu sniedzējs ir pienācīgi brīdinājis ieguldītāju un ieguldītājs ir pieṇēmis apzinātu un pārdomātu lēmumu par aktīvu nodošanu turēšanā, pien,emot attiecīgus riskus.

Ar FITL 26. grozijjumiem ieguldijumu pakalpojumu sniedzējiem tika aizliegts ar privātajiem klientiem noslēgt līgumus ar nodrošinājumu par īpašumtiesību nodošanu, respektīivi, aizliegta tāda finanšu instrumentu turēšanas prakse, kas vērsta uz finanšu instrumentu škirtas turēšanas nenodrošināšanu, t. i., tādu režīmu, kurā finanšu instrumentu juridiskais īpašnieks ir ieguldījumu pakalpojumu sniedzējs, savukārt pats ieguldītājs ir tiesīgs rīkoties ar finanšu instrumentiem (piemēram, atsavināt, iegādāties jaunus u. tml.), saṇemt no tiem augḷus un citus ienākumus. 
Šis aizliegums, domājams, pilnīgi nepamatoti tiek piemērots arī repo darījumiem, kas tiek uzskatīti par "līgumiem par finanšu nodrošinājumu ar ìpašuma tiesību pāreju" atbilstoši Finanšu nodrošinājuma likuma 1. panta sestajam punktam [4]. Repo darïjumos pārdevējs - atšķirībā no iepriekš aprakstītā gadījuma - zaudē tiesības rīkoties ar finanšu instrumentiem, t. sk. lemt par finanšu instrumentu atsavināšanu. Viņam nav îpašnieka tiesību uz finanšu instrumentiem darījuma laikā, un šì ir būtiska atšķirība starp abiem gadījumiem: aizliegums ir vērsts uz ieguldītāja interešu aizsardzības nodrošināšanu, kas tiek sasniegta, piemērojot šķirto turēšanu aktīvu saglabāšanai; otrajā gadỉjumā ieguldìtājs saṇem finansiālu labumu (naudu) par pārdoto finanšu instrumentu, un viṇam pēc būtības vairāk nav nekādu tiesību attiecībā uz šo finanšu instrumentu līdz brīdim, kad nauda netiks atmaksāta. Nav skaidrs, kādēl būtu jāierobežo privāta klienta tiesības noslēgt repo darïjumus, pamatojot to ar aizliegumu, kas vērsts uz finanšu instrumentu turēšanas risku mazināšanu.

Produktu pārvaldība. Ar FITL 26. grozījumiem ieviesti pilnīgi jauni procesi attiecībā uz pakalpojumu un produktu pārvaldības prasībām, proti, paredzēta ieguldījumu pakalpojumu sniedzēja kā ieguldījumu produkta ražotāja vai izplatītāja civiltiesiskā atbildība par informācijas sniegšanu sakarā ar ieguldījumu produktu - novērojami vairāki atbildības virzieni: atbildība par informācijas nesniegšanu, atbildỉba par nepareizu / nepatiesu informāciju, atbildība par nepareiza "mērḳa tirgus" noteikšanu. Kaut arī, domājams, šādas atbildības apmērs ir ierobežots ar to zaudējumu apmēru, ko ieguldītājs ir cietis, tomēr vienmēr radīsies jautājumi par ieguldītāja statusu, personību un ieguldītāja spēju uztvert informāciju nepareiza mērḳa tirgus noteikšanas gadỉjumos.

Interešu konflikts. Atšḳirībā no regulējuma, kas tika ieviests ar MiFID grozījumiem, pēc FITL 26. grozỉjumu ieviešanas mainījās pieeja interešu konflikta pārvaldǐšanai. Ja ar MiFID grozijumiem ieguldijjumu pakalpojumu sniedzējiem tika uzlikts pienākums identificēt interešu konfliktus un tos atklāt, tad ar FITL 26. grozïjumiem tika uzlikts pienākums identificēt interešu konfliktus un novērst tos, savukārt, ja interešu konflikta pilnīga novēršana nav iespējama, tad atklāt to un informēt par to ieguldītāju. Respektīvi, ieguldījumu pakalpojumu sniedzējam jāizvērtē ne tikai potenciālie interešu konflikta gadījumi, kas veidojas starp ieguldījumu pakalpojumu sniedzēju un ieguldītāju, bet arī situācijas, kas veidojas starp ieguldïjuma pakalpojuma sniegšanā iesaistīto personu un ieguldītāja interesēm, arī starp vairāku ieguldītāju interesēm u. tml.

Bez interešu konflikta novēršanas pienākuma ar interešu konfliktu novēršanu ir saistīti arī citi jauninājumi, kas attiecas uz labumu saṇemšanu no ieguldījumu pakalpojumu sniedzēja darījumu partneriem, kā arī aizliegumu saṇemt labumus retrocesijas gadījumos, kad tiek sniegts portfel̦u pārvaldības pakalpojums vai konsultācija. Ar interešu konflikta novēršanu saistīti grozījumi, kas attiecas uz sniegto konsultāciju veidiem, pamudinājumu atklāšanu u. tml. 
Tatjana Jukna. Ieguldītāju aizsardzības mehānisma attīstības tendences: normatīvo aktu grozijumi 2017. un 2018. gadā

\section{Secinājumi}

1. FITL 2017. un 2018. gadā tika veikti apjomīgi grozījumi ieguldītāju interešu aizsardzības veicināšanai. Šeit netika aprakstīti visi Latvijas normatīvajā regulējumā pārṇemtie jauninājumi, ieviešot Eiropas Savienības direktīvas. Latvijas Republikas normatīvo regulējumu ieguldījumu pakalpojumu jomā harmonizācijas procesi stipri ietekmēja normatīvā regulējuma struktūru, proti, tajā novērojama normatīvā regulējuma "dekodifikācijas" stingra tendence. Ja pirms 26. grozījumu pieņemšanas visas svarīgās normas bija ietvertas FITL, tad pēc grozījumiem, šīs normas tika daḷēji izslēgtas, jo kopā ar citiem būtiskajiem pienākumiem, tās ietvertas vairākās delegètajās regulās. Rezultātā vairs nepastāv vienots "kodificēts" likums, kurā var ieskatīties un iegūt pilnu priekšstatu par tiesību un pienākumu apjomu konkrētajā jautājumā, kā tas bija iepriekš.

2. Regulējums kḷūst arvien komplicētāks, un novērojama spilgti izteikta pārregulācija, kas ievērojami palielina administratīvo slogu ieguldījumu pakalpojumu sniedzējiem.

3. Tiesiskajā regulējumā ietvertas vairākas normas, uz kuru pamata ieguldītājs var prasīt zaudējumu atlīdzināšanu no ieguldījumu pakalpojumu sniedzēja. Viens šāds piemērs var būt ieguldījumu pakalpojumu sniedzēja pienākumu precizēšana saistībā ar šḳirtas turēšanas nodrošināšanu. Rezultātā ir kḷuvis skaidrāks ieguldījumu pakalpojuma sniedzēja, kas nodrošina turēšanas pakalpojumus, civiltiesiskās atbildības ietvars, kas iepriekš bija ḷoti vāji noteikts.

4. Būtiski pieaudzis informācijas apjoms, ko ieguldïjumu pakalpojumu sniedzējam jāsniedz ieguldītājam, lai ieguldītājs varētu pieṇemt pārdomātu un atbildīgu lēmumu. Domājams, ka lielā informācijas daudzuma dēl, ko saṇem ieguldītājs, viņam svarīga informācija var pazust vai palikt nepamanīta, jo informācijas apjoms var izrādīties pārlieku liels.

\section{Development of Investor Protection Mechanism: Ammendments to the Law in 2017-2018}

\section{Abstract}

Mechanism of the investor protection is a quite new law institute. The elements of the investor protection mechanism could be found in various legal acts both at the state level of the Republic of Latvia and at the level of the EU. Globalisation, technical developments and arising of new types of financial instruments encourage actualisation of investor protection problematics. 
Tatjana Jukna. Ieguldītāju aizsardzības mehānisma attīstības tendences: normativo aktu grozijumi 2017. un 2018. gadā

The development of the measures related to the investor protection are influenced by the transportation of the EU legal acts into national law systems. The article is devoted to the rights of investors as elements of investor protection mechanisms in the aspect of providing of investment services to the investors.

Keywords: investors, investor protection, MIFID II, financial instruments, law on the market of financial instruments, Repo transactions.

\section{Avoti un literatūra}

\section{Tiesību akti}

1. Alternatīvo ieguldījumu fondu un to pārvaldnieku likums: Latvijas Republikas likums: pieñemts 09.07.2013. un stājās spēkā 07.08.2013. Latvijas Vēstnesis. 142(4948), 24.07.2013.

2. Eiropas Parlamenta un Padomes Direktīva 2014/65/ES 2014. gada 15. maijā par finanšu instrumentu tirgiem un ar ko groza Direktīvu 2002/92/ES un Direktīvu 2011/61/ES: Eiropas Parlamenta un Padomes Direktīva. Eiropas Savienības Oficiālais Vēstnesis. OJ L 173, 12.06.2014.

3. Finanšu instrumentu tirgus likums: Latvijas Republikas likums: pieņemts 20.11.2003. un stājās spēkā 01.01.2004. Latvijas Vēstnesis. 175(2940), 11.12.2003.

4. Finanšu nodrošinājuma likums: Latvijas Republikas likums: pieñemts 21.04.2005. un stājās spēkā 25.05.2005. Latvijas Vēstnesis. 74(3232), 11.05.2005.

5. Finanšu un kapitāla tirgus komisijas likums: Latvijas Republikas likums: pieṇemts 01.06.2000. un stājās spēkā 01.07.2001. Latvijas Vēstnesis. 230/232, 20.06.2000.

6. Ieguldītāju aizsardzības likums: Latvijas Republikas likums: pieṇemts 08.11.2001. un stājās spēkā 01.01.2002. Latvijas Vēstnesis. 170 (2557), 23.11.2001.

7. Ieguldijjumu pārvaldes sabiedrību likums: Latvijas Republikas likums: pieṇemts 18.12.1997. un stājās spēkā 01.07.1998. Latvijas Vēstnesis. 342/345(1054/1057), 30.12.1997.

8. Imigrācijas likums: Latvijas Republikas likums: pieṇemts 31.10.2002. un stājās spēkā 01.05.2003. Latvijas Vēstnesis. 169(2744), 20.11.2002.

9. Jaunuzñēmumu darbības atbalsta likums: Latvijas Republikas likums: pieñemts 23.11.2016. un stājās spēkā 01.01.2017. Latvijas Vēstnesis. 241(5813), 10.12.2016.

10. Kredītiestāžu likums: Latvijas Republikas likums: pieņemts 05.10.1995. Latvijas Vēstnesis. 163(446), 24.10.1995.

11. Krimināllikums: Latvijas Republikas likums: pieṇemts 17.06.1998. un stājās spēkā 01.04.199. Latvijas Vēstnesis. 199/200(1260/1261), 08.07.1998.

12. Par vērtspapīriem: Latvijas Republikas likums: pieṇemts 23.08.1995. un zaudējis spēku. Latvijas Vèstnesis. 138, 12.09.1995.

\section{Literatūra}

13. Akadēmiskā terminu datubāze AkadTerm. Iegūts no: http://termini.lza.lv/term.php?term=ieg uld\%C4\%ABt\%C4\%81js\&lang=LV [sk.18.03.2019.].

14. Brīdinājums investoriem par jaunu finanšu investīciju pakalpojumu - sākotnējiem virtuālās valūtas piedāvājumiem - vai Initial Coin Offering (ICO) un tā riskiem. Finanšu un kapitāla tirgus komisija. 17.11.2017. Iegūts no: https://www.fktk.lv/klientu-aizsardziba/bridinajumsinvestoriem-par-jaunu-finansu-investiciju-pakalpojumu-sakotnejiem-virtualas-valutas-piedavajumiem-vai-initial-coin-offering-ico-un-ta-riskiem/ [sk. 18.03.2019.]. 
Tatjana Jukna. Ieguldītāju aizsardzības mehānisma attīstības tendences: normatīvo aktu grozijumi 2017. un 2018. gadā

15. Cambridge Dictionary. Iegūts no: https://dictionary.cambridge.org/dictionary/ [sk.18.03.2019.]. 16. Eurotermbank. Iegūts no: http://www.eurotermbank.com [sk.18.03.2019.].

17. Financial Times. Iegūts no: http://lexicon.ft.com/Term?term=investor-protection [sk.18.03.2019.]. 18. Juridisko terminu vārdnīca. Rīga: Nordik, 1998.

19. Liepiṇš, A. MiFID II - vai efektīva atbilde krīzes cēloṇiem un vai gala investīciju patērētāji būs labāk pasargāti? Dienas Bizness. 09.04.2018. Iegūts no: https://www.db.lv/zinas/jau-sogad-t/ mifid-ii-vai-efektiva-atbilde-krizes-celoniem-un-vai-gala-investiciju-pateretaji-bus-labak-pasargati-473837 [sk.18.03.2019.].

20. Mantrovs, V. 2018. Apdrošināšanas tiesības. Rīga: LU akadēmiskais apgāds. 